удк 342.9

Ю.І. Цвіркун

\title{
ЩОДО ВТРУЧАННЯ АДМІНІСТРАТИВНОГО СУДУ У РОЗСУД КОЛЕГІАЛЬНИХ СУБ'СКТІВ ПУБЛІЧНОЇ АДМІНІСТРАЦІЇ
}

Постановка проблеми. Чинне законодавство України закріплює, що адміністративні суди здійснюють контроль за діяльністю суб’ єктів публічної адміністрації. Саме адміністративне судочинство $€$ механізмом правового захисту особи від довільного втручання суб'єктів владних повноважень у її права і свободи. Таке довільне втручання у права і свободи особи доволі часто відбувається з боку колегіальних суб'єктів публічної адміністрації. Контроль же адміністративного суду полягає в перевірці рішень, дій чи бездіяльності відповідних суб’єктів, а також у забезпеченні захисту прав, свобод та інтересів фізичних осіб, прав та інтересів юридичних осіб та обов'язковому відновленню у разі їх порушення. Для виконання завдань адміністративного судочинства адміністративним судам законом надається компетенція на власний розсуд впливати на адміністративний розсуд будь-яких суб'єктів, які здійснюють владні управлінські функції на основі законодавства, у тому числі на виконання делегованих повноважень. Способи впливу адміністративного суду на відповідних суб’єктів є різними. Одним із цих способів, який має місце і застосовується доволі часто у вітчизняному адміністративному судочинстві, $€$ втручання суду у розсуд суб’єктів публічної адміністрації. Таке втручання адміністративного суду повною мірою стало можливим з прийняттям у 2005 році Кодексу адміністративного судочинства України (далі - КАСУ) та запровадженням адміністративної юстиції. Вважаємо, що здійснення правового аналізу підходів до розуміння цього явища має актуальне значення на сучасному етапі реформування судової системи, а дослідження проблемних питань, які виникають у зв'язку із втручанням адміністративного суду у розсуд колегіальних суб’єктів публічної адміністрації, $є$ новим у вітчизняній науці адміністративного права.

Метою статті є здійснення правового аналізу підходів до розуміння такого явища, як втручання адміністративного суду в адміністративний розсуд та дослідження проблемних питань, які виникають у зв'язку із втручанням суду у розсуд колегіальних суб'єктів публічної адміністрації.

Виклад основного матеріалу. Колегіальні суб’єкти публічної адміністрації, враховуючи їх адміністративно-правовий статус та особливості його реалізації, нами класифіковано на державні та недержавні.

До державних колегіальних суб’єктів публічної адміністрації віднесено, зокрема: органи виконавчої влади (Кабінет Міністрів України, Антимонопольний комітет України та інші); національні комісії регулювання природних монополій (Національна комісія, що здійснює державне регулювання у сфері ринків фінансових послуг, Національна комісія, що здійснює державне регулювання у сферах енергетики та комунальних послуг та інші); органи суддівського самоврядування та врядування (з'їзд суддів України, Рада суддів України, Вища рада правосуддя (далі - ВРП), Вища кваліфікаційна комісія суддів України (далі - ВККСУ); інші суб’єкти, що мають певні особливості в адліністративно-правовому статусі (Національна рада України

() Ю. І. Цвіркун, 2019 
з питань телебачення і радіомовлення, Центральна виборча комісія, Рахункова палата та інші).

До недержавних колегіальних суб'єктів віднесено, зокрема: органи місиевого самоврядування (місцеві ради, виконавчі комітети представницьких органів місцевого самоврядування та інші); суб’єкти делегованих повноважень (до прикладу, громадські об’єднання, яким держава або представницькі органи місцевого самоврядування адресують певні адміністративні функції та окремі повноваження - громадські природоохоронні організації, громадські формування з охорони громадського порядку і державного кордону тощо).

Правозастосувальний розсуд - це передбачене юридичними нормами повноваження правозастосувального суб'єкта обирати один з декількох дозволених ними варіантів рішення щодо встановлення застосованої норми, з'ясування (тлумачення) їі змісту або визначення міри конкретизації суб'єктивних юридичних прав і обов'язків, що реалізується у певній процесуальній формі з огляду на зміст цієї норми та конкретні обставини справи та інші юридично значущі факти з метою забезпечення законності, справедливості, доцільності та ефективності державно-правового регулювання [1, с. 8].

Традиційно правозастосувальний розсуд у науці адміністративного права поділяється на дві основні групи, а саме: адміністративний розсуд, який здійснюється суб’єктами владних повноважень у разі виконання ними владних управлінських функцій; розсуд адміністративного суду, що здійснюється під час відправлення правосуддя, завданням якого є контроль легальності публічної адміністрації.

Вивчення такого поняття, як адміністративний розсуд, привело нас до відповідної його характеристики. Насамперед адміністративний розсуд - це певний ступінь свободи, яка у визначених законом межах надається суб'єкту публічної адміністрації у вирішенні різного роду правових справ. Ця свобода надається для того, щоб була можливість прийняти найраціональніше рішення в конкретній ситуації. Таке рішення обирається через оцінювання фактичних обставин справи та на виконання законної мети. Під час реалізації наданих повноважень такий суб'єкт, маючи свободу вибору ухвалювати одне із декількох рішень, виконує інтелектуально-вольову діяльність з урахуванням підстав, меж та способів, передбачених законодавчими приписами. У разі реалізації таких дискреційних повноважень цим суб'єктом мають поважитися основоположні права і свободи особи та дотримуватися загальні принципи права. Адміністративний розсуд $є$ невід'ємною складовою частиною здійснення владних управлінських функцій.

Обрані суб’єктом владних повноважень рішення чи дія (утримання від дій) у разі оскарження до суду підлягають оцінці адміністративним судом. Наявність у адміністративного органу права на розсуд та наявність у суду компетенції на здійснення його оцінки та втручання у цей розсуд породжує необхідність у всебічному вивченні проблем, які виникають у зв'язку із діяльністю колегіальних суб'єктів публічної адміністрації під час виконання дискреційних повноважень, а також із впливом адміністративних судів на поведінку цих органів.

Прийнято вважати, як зазначає професор М. Савчин, що під суддівським розсудом слід розуміти «вихідний принцип здійснення правосуддя, що полягає у гарантуванні суб’єктові правозастосування (судді) правомочностей щодо обрання найбільш оптимального варіанта вирішення правового питання відповідно до нормативно визначе- 
них меж, вихідних засад і цілей права, конкретних обставин справи» [2]. Фактично суддівський розсуд врегульовано правовими нормами, підкреслює вчений-практик Л. Лічман, і є здійснюваним у процесуальній формі специфічним видом правозастосовної діяльності, сутність якої полягає в наданні суду у відповідних випадках можливості вирішувати спірне правове питання, виходячи з цілей, переслідуваних законодавцем, принципів права та інших спільних положень закону, конкретних обставин справи, а також принципів розумності, сумлінності, справедливості та основ моралі [3].

На думку вчених В. Бевзенка та Г. Панової, процесуальний розсуд адміністративного суду - врегульована нормами адміністративного процесуального права та заснована на нормах матеріального права й фактичних обставинах можливість адміністративного суду, який розглядає та вирішує справу, обирати на власний вибір процесуальне рішення [4, с. 71].

На органи законодавчої, виконавчої та судової влади покладається обов' язок здійснювати свої повноваження згідно із встановленими Конституцією України засадами та у відповідності до законів України. Розмежування розсуду адміністративного суду від управлінського розсуду суб'єктів владних повноважень передбачено приписами Основного Закону та інших законодавчих актів. Деталізація повноважень суду на здійснення процесуального розсуду та можливого втручання у розсуд публічної адміністрації передбачена нормами процесуального права, які закріплені у КАСУ.

Науковець О. Ільницький зауважує, що порушення прав, свобод та інтересів особи може відбуватися суб'єктом владних повноважень двома способами - пасивним (шляхом нерозгляду питання щодо реалізації прав) та активним (шляхом відмови в реалізації прав особи, найчастіше обгрунтовуючи це дискреційними повноваженнями й наявністю можливостей самостійно вирішувати відповідні питання). В обидвох цих випадках реальний, а не формальний захист і відновлення порушеного права позивача не лише вимагає визнання протиправними дій (бездіяльності), а й, оскільки така діяльність прямо суперечить Конституції України, законам і спеціально-дозвільним принципам діяльності суб'єктів владних повноважень, захист має відбуватися шляхом спонукання до виконання компетенційного обов'язку легалізувати своїм рішенням чи дією передбачене право особи [5].

Тож судовий захист має бути відчутним. Правосуддя має бути не лише завершеним, але і таким, щоб було помітно, що воно відбулося. Із прийняттям судового рішення, а надалі з його виконанням, мають бути розставленні всі крапки над «і» - порушене право має бути захищеним та відновленим, а суб'єкт публічної адміністрації, який допустив порушення, - понести відповідальність. Уважаємо, що вітчизняне законодавство потребує негайного і суттєвого удосконалення в аспекті нормативно-правового закріплення питань відповідальності колегіальних органів. Тільки тоді адміністративне правосуддя відповідатиме вимогам справедливості, коли забезпечуватиме повне поновлення прав, свобод і інтересів особи та гарантуватиме відповідальність правопорушника.

Розсуд як такий є необхідним елементом правозастосовчої діяльності судів і адміністративних органів. Але доходимо висновку, що судовий розсуд адміністративного суду суттєво відрізняється від адміністративного розсуду (управлінського розсуду). 
Насамперед відмінність полягає у тому, що адміністративний розсуд здійснюється суб'єктом публічної адміністрації у зв'язку із виконанням ним владних управлінських функцій, а судовий розсуд полягає саме у «розсуді» судом його управлінської діяльності у зв'язку з оскарженням рішення, дії чи бездіяльності такого суб'єкта. В обранні способу захисту особи суд наділений правами щодо примусу до реалізації повноважень суб'єктом публічної адміністрації у спосіб, визначений законом. Суб'єкт владних повноважень не вправі самовільно визначати свою правову поведінку, оскільки вона має чітко відповідати нормі закону. Адміністративний суд же має певні «вільні люфти» у своїй діяльності, зокрема, вони йому надаються законом під час ухвалення рішення по суті спору.

Ще у 2008 році Верховний Суд України у пункті 14 листа від 29.10.2008 № 19-3767/0/8-08 роз'яснив, що під час розгляду справ за адміністративними позовами до органів державної влади чи органів місцевого самоврядування про визнання неправомірною бездіяльності щодо нерозгляду заяви про надання земельної ділянки в оренду, про передачу земельної ділянки у власність, суди вправі зобов'язати відповідний орган розглянути зазначене питання, а не приймати рішення про надання в оренду (передачу у власність), що не належить до компетенції суду [6].

Окрім іншого, законодавство України про судоустрій передбачає, що судді (суду) забезпечується свобода неупередженого вирішення справ відповідно до їх внутрішнього переконання. Суддя здійснює правосуддя на основі Конституції і законів України, керуючись при цьому принципом верховенства права.

У пункті 10.3 Постанови Пленуму Вищого адміністративного суду України (далі ВАСУ) «Про судове рішення в адміністративній справі» від 20.05.2013 року № 7 судам роз'яснювалось, що у разі визнання судом неправомірними дій чи бездіяльності відповідача суд може зобов'язати його вчинити чи утриматися від вчинення певних дій у спосіб, визначений чинним законодавством, яким може бути захищено/відновлено порушене право. Резолютивна частина рішення не має містити приписів, що прогнозують можливі порушення з боку відповідача та зобов'язання його до вчинення чи утримання від вчинення дій на майбутнє. Суд може ухвалити постанову про зобов'язання відповідача прийняти рішення певного змісту, за винятком випадків, коли суб’єкт владних повноважень під час адміністративних процедур відповідно до закону приймає рішення на основі адміністративного розсуду [7].

Тобто вищий судовий орган у системі адміністративних судів, спираючись на норми КАСУ, що діяли тоді, застерігав нижчестоячі суди від втручання у сферу, яка належить до повноважень суб'єктів, що здійснюють управлінську діяльність.

Найбільші проблеми виникають у разі розгляду справи в адміністративному суді, оскільки суди через принцип поділу влади, гарантованого Конституцією через принцип правової держави, мають право перевіряти лише правомірність дій виконавчої влади, але доцільність її рішень не підпадає під судову перевірку. Це означає, що в суді може бути заявлена лише вимога про встановлення наявності таких помилок, як незастосування розсуду, порушення меж розсуду і неправильне застосування розсуду [8]. Отже, суб'єктом публічної адміністрації у процесі своєї діяльності може бути допущена протиправна бездіяльність та/або вчинення дій чи прийняття рішення з перевищенням наданих повноважень або не на підставі та не у спосіб, що визначені у законі. 
Суддівський розсуд супроводжується внутрішнім процесом мислення, спрямованим на вибір оптимального варіанту розв'язання спірного правового питання, пошук необхідної правової норми, її розуміння та інтерпретацію, справедливе вирішення спору. Суддівський розсуд здійснюється на різних стадіях судочинства незалежно від його виду - конституційного, адміністративного, цивільного, господарського, кримінального у випадках, дозволених або не врегульованих законом [9]. Розсуд судді є суто правовим явищем, має місце лише у визначених законом випадках, підлягає оцінці допустимості його реалізації згідно з вимогами законності та іншими принципами права [10]. На основі дискреційних повноважень суддя може відступити від суто нормативного правового регулювання і вирішити справу на основі принципів права. Отже, судовий розсуд забезпечує дієвість принципу верховенства права [11].

Разом із тим судовий розсуд не завжди має місце у судовій діяльності. Принаймні трапляються випадки, коли суд (суддя) має до вибору лише один варіант вирішення справи - законний.

Коли є тільки один законний варіант, розсуду немає. У такій ситуації від судді вимагається вибрати цей варіант, і у нього немає жодної свободи вибору. Про жодний розсуд не може йтися, коли вибір має здійснюватися між законним актом і незаконним актом. Суддя мусить вибрати законний акт, він не має права вибирати акт незаконний. Розсуд же, з іншого боку, передбачає відсутність обов'язку вибрати одну певну можливість із декількох. Розсуд передбачає наявність декількох варіантів, з яких суддя уповноважений вибрати один, що, на його погляд, найбільш вдалий [12, с. 14].

В. Бевзенко і Г. Панова доводять існування двох видів процесуального розсуду адміністративного суду залежно від його мети та спрямованості: процесуальний розсуд адміністративного суду, який засто-совується ним для організації, забезпечення та керування розглядом та вирішенням адміністративної справи. Такий вид розсуду адміністративного суду не може застосовуватися для оцінки, зміни чи скасування рішень, дій, бездіяльності суб'єкта публічної адміністрації; процесуальний розсуд адміністративного суду ( пправозахисний» ( пправопоновлювальний») процесуальний розсуд адміністративного суду), який застосовується ним під час ухвалення рішення по суті щодо рішень, дій, бездіяльності суб'єкта публічної адміністрації, які стали предметом оскарження та дослідження в адміністративному суді [4, с. 205-206].

Саме під час здійснення «правозахисного» процесуального розсуду адміністративного суду, як правило, може відбуватися втручання суду у розсуд органу виконавчої влади чи органу місцевого самоврядування. У цьому разі має значення границя такого втручання, оскільки під час переходу визначеної законом границі буде мати місце «свавільне втручання» суду в діяльність іншого органу влади, що є неприпустимим.

Поняття судового розсуду в адміністративному судочинстві можна визначити як: передбачене законодавством право суду, яке реалізується з дотриманням встановленої процесуальної форми здійснення правосуддя в адміністративних справах, надає йому можливість під час прийняття судового рішення (вчинення процесуальної діі) вибрати з декількох варіантів рішення (дії), встановлених законом чи визначених на його основі судом (повністю або частково за змістом та/чи обсягом), найбільш оптимальний в правових і фактичних умовах розгляду та вирішення конкретної справи 
з метою забезпечення верховенства права, справедливості та ефективного поновлення порушених прав та інтересів учасників процесу [10].

На нашу думку, задля забезпечення справедливості та ефективного поновлення порушених прав та інтересів особи втручання адміністративного суду в адміністративний розсуд в окремих категоріях судових справ, зокрема, відповідачами в яких є колегіальні суб'єкти, в сучасних умовах є неминучим.

Втручання адміністративного суду у розсуд суб’єкта публічної адміністрації полягає у зобов'язанні цього суб'єкта до реалізації його повноважень щодо здійснення адміністративної процедури або щодо ухвалення рішення, вчинення дії, утримання від рішення чи дії $[4$, с. 79$]$.

Звернемось до практики ВАСУ з цього приводу. Так, в ухвалі ВАСУ від 12.01.2017 року № К/800/21531/16 зроблено висновок, що втручання мало бути зумовлене досягненням правомірної цілі [13]. Крім того, з посиланням на правові положення, які зазначені у пункті 56 Рішення Європейського суду з прав людини (далі-ЄСПЛ) у справі «Олссон проти Швеції» від 24.03.1988 року (скарга № 10465/83) вітчизняний судовий орган обгрунтував свою позицію щодо застосування способу захисту. Зокрема, ВАСУ звертає увагу на те, що у цьому Рішенні ЄСПЛ зазначено, що серед вимог, які визначено як такі, що випливають з фрази «передбачено законом», $€$ такі: будь-яка норма не може вважатися «законом», якщо вона не сформульована з достатньою точністю так, щоб громадянин самостійно або, якщо знадобиться, з професійною допомогою міг передбачити з часткою ймовірності, яка може вважатися розумною в цих обставинах, наслідки, які може спричинити за собою конкретну дію; фраза «передбачено законом» не просто відсилає до внутрішнього права, але має на увазі і якість закону, вимагаючи, щоб останній відповідав принципу верховенства права. У внутрішньому праві мають існувати певні заходи захисту проти свавільного втручання публічної влади у здійснення прав; закон, який передбачає дискреційні повноваження, сам по собі не $є$ несумісним з вимогами передбачуваності за умови, що дискреційні повноваження та спосіб їх здійснення вказані з достатньою ясністю для того, щоб з урахуванням правомірності мети зазначених заходів забезпечити індивіду належний захист від свавільного втручання влади [14].

Тож втручання в адміністративний розсуд має бути зумовлене лише досягненням правомірної цілі.

Як підсумок, вищий судовий орган у системі адміністративних судів підкреслив, що суди мають відновлювати порушене право шляхом зобов'язання відповідного суб'єкта владних повноважень прийняти конкретне рішення [13].

Правові норми адміністративного законодавства мають містити конкретні і чіткі положення щодо характеру дискреційних повноважень, особливостей їх реалізації, деталізувати рамки, в межках яких надається воля для розсуду суб'єкту владних повноважень. Діапазон адміністративного розсуду має бути звужений і настільки визначений законом, щоб вихід за його межі був одразу помітним. Однак законодавство України, яке нині $€$ чинним, не містить відповідних критеріїв, воно $€$ не досить чітким, має чимало недоліків. Оскільки нормативне регулювання реалізації адміністративними органами дискреційних повноважень $€$ поверховим, на систему адміністративних судів нині покладається завдання посиленого контролю за діяльністю публічної адміністрації. 
Доходимо до того, що на підставі закону адміністративний суд має повноваження на втручання у розсуд публічної адміністрації. Однак залежно від ступеня втручання можемо говорити про «правомірне втручання» $\mathrm{i}$ «неправомірне втручання». Останне буде мати місце тоді, коли суд перевищує свої повноваження і переходить встановлені законом межі своєї компетенції.

Наскільки суду дозволяється втручатися у діяльність суб'єкта владних повноважень? Вважаємо, що таке втручання має бути у межах закону і визначається судом самостійно. У разі відсутності конкретного законодавчого припису щодо втручання суду слід знаходити одне із рішень, яке не суперечить закону і відповідає загальним принципам права. Крім того, на нашу думку, втручання має бути до тієї міри, поки судом не буде захищено право особи і надалі повністю не відновлене. Висновок про те, чи мало місце «правомірне втручання» чи «неправомірне втручання» судом, на наш погляд, може робити лише суд вищої інстанції у порядку перегляду судового рішення. Але у жодному разі не суб'єкт владних повноважень, зокрема, який є відповідачем.

$€$ думка, що оскільки судді добираються на професійній основі, а засадою легітимності їхніх рішень $є$ вимога обгрунтованості, то вони мають переваги перед актами парламенту чи іншої легіслатури, наділеної регуляторними функціями, позаяк рішення останніх грунтуються на політичних обставинах [2].

Завданням судової влади є захист державного і конституційного ладу, але основним пріоритетом адміністративних судів є сприяння фізичним і юридичним особам у реалізації їхніх прав, свобод та інтересів. Призначенням адміністративного суду є конкретизація і деталізація чинних норм права, які регулюють суспільні відносини у публічній сфері. Суду, порівнюючи його повноваження із повноваженнями органів виконавчої влади, органів місцевого самоврядування, їхніми посадовими і службовими особами, інших владних суб'єктів, законом надається найширше поле для розсуду. Звичайно, для суду законом також визначені способи досягнення необхідного результату. Проте норми процесуального права, закріплені у КАСУ, надають суду у його правозахисній діяльності більшої свободи вибору та передбачають низку альтернатив таких способів.

При цьому, на нашу думку, чим вища судова інстанція, тим ширша свобода розсуду. Правові межі судового розсуду формуються судами вищих інстанцій. Сталість судової практики забезпечується шляхом закріплення обов'язковості рішень Верховного Суду, який у правових позиціях визначає межі судового розсуду.

Г. Панова робить висновок, що втручання адміністративного суду в розсуд суб'єкта публічної адміністрації слід характеризувати й оцінювати диференційно, а саме: втручання адміністративного суду може стосуватися адміністративної процедури ухвалення рішення, вчинення дії і полягати у визнанні такої процедури незаконною, необгрунтованою або нечинною, зобов'язанні суб'єкта публічної адміністрації провести таку процедуру повторно або утриматися від подальшої реалізації такої процедури; втручання адміністративного суду може стосуватися активного прояву реалізації компетенції суб’єкта публічної адміністрації (ухвалення рішення, вчинення дії) й полягати у визнанні такого рішення, дії незаконними, необгрунтованими або нечинними, встановленні заборони на подальшу реалізацію ухваленого рішення чи продовженні вчинення дій; втручання адміністративного суду може стосуватися бездіяльності 
суб’єкта публічної адміністрації й полягати у визнанні такої бездіяльності незаконною, необґрунтованою або нечинною, зобов' язанні суб'єкта публічної адміністрації до ухвалення рішення, вчинення дії [15].

Часто у науковій літературі звертається увага на те, що втручання суду має бути законним і не виходити за межі правового поля. У разі якщо таке втручання відбувається із перевищенням, то закладається підгрунтя для конфлікту між судом та суб'єктом публічної адміністрації. Вихід за межі правового поля судом у разі прийняття судового рішення негативно впливає на роботу інших органів влади.

Разом із тим кількість адміністративних справ у судах зростає. Статистика вказує, що проваджень в адміністративних справах тисячі. Адміністративні суди найбільш завантажені, порівнюючи із судами інших спеціалізацій у системі судоустрою України. Така велика кількість публічно-правових спорів породжується протиправною поведінкою органів державної влади, органів місцевого самоврядування, інших суб'єктів під час здійснення ними владних управлінських функцій. Отже, випливає висновок, що найчастіше порушують закон суб'єкти владних повноважень.

Втручання адміністративного суду в управлінський розсуд $є$ вимушеним кроком. Воно здійснюється з метою захисту та відновлення порушених прав, свобод та інтересів приватної особи. Зауважимо, що чітких меж втручання суду у розсуд суб'єкта публічної адміністрації закон не установлює і ці межі визначаються судом самостійно з урахуванням певних чинників. Такі чинники під час розгляду та вирішення судової справи можуть бути різними. Зокрема, суд має зважати на засади судочинства, приписи норм матеріального і процесуального права, обставини справи, позовні вимоги та обгрунтування позову, адміністративно-правовий статус відповідача і його повноваження, позицію відповідача, моральні принципи та інші чинники. Суд має керуватися принципом верховенства права. У разі відсутності закону він застосовує аналогію закону або аналогію права.

Ми погоджуємось, що судовий орган не має перевищувати межі свого втручання у діяльність суб'єкта владних повноважень. Однак його втручання має бути ефективним та достатнім для забезпечення виконання завдань адміністративного судочинства.

Через демократизацію органів публічної влади в Україні кількість колегіальних суб’єктів публічної адміністрації збільшується, що потребує дослідження їх статусу, компетенції та меж відповідальності в процесі реалізації наданих повноважень [16]. Також вважаємо, що наукового дослідження потребує вплив адміністративного суду на реалізацію повноважень колегіальними владними суб'єктами під час здійснення судового контролю за їх поведінкою. До судових процесів, відповідачами у яких є колегіальні суб'єкти публічної адміністрації, як правило, прикутий особливий суспільний інтерес, тому питання можливого втручання судом у їх управлінський розсуд, 3 огляду на їх адміністративно-правовий статус, мають бути виразно зрозумілими.

На думку Г. Панової, втручання адміністративного суду в адміністративний розсуд залежить від часу його застосування і може бути таких видів: 1) поточне втручання здійснюється адміністративним судом під час розгляду та вирішення адміністративної справи до ухвалення постанови в справі. Таке втручання має тимчасовий характер; 2) втручання за підсумками розгляду та вирішення адміністративної справи (наступне втручання) [15]. 
Що стосується поточного втручання, то воно є інструментом тимчасового захисту прав, свобод та інтересів особи в адміністративному суді до вирішення адміністративної справи по суті. Тимчасові заходи захисту мають чітке вираження у нормах процесуального права i, як правило, не містять альтернатив.

Втручання за підсумками розгляду та вирішення адміністративної справи може бути у разі задоволення адміністративного позову до суб'єкта владних повноважень, коли на підставі встановлених у справі обставин суд доходить висновку, що його рішення, дії чи бездіяльність є протиправними повністю або частково.

У статті 5 КАСУ закріплено право на звернення до суду та визначені способи судового захисту [17]. Так, у частині першій статті 5 КАСУ закріплені способи захисту, про які може просити позивач - особа, яка вважає, що рішенням, дією чи бездіяльністю суб'єкта владних повноважень, у тому числі і колегіального, порушені її права, свободи або законні інтереси.

Разом із тим частина друга статті 5 КАСУ передбачає, що захист порушених прав, свобод чи інтересів особи, яка звернулася до суду, може здійснюватися судом також в інший спосіб, який не суперечить закону і забезпечує ефективний захист прав, свобод, інтересів людини і громадянина, інших суб'єктів у сфері публічно-правових відносин від порушень з боку суб’єктів владних повноважень [17].

Стаття 245 КАСУ установлює повноваження суду під час вирішення справи, у частині другій якої в п'ятнадцяти пунктах також перелічені способи захисту особи, які застосовує суд у разі задоволення позову. Комплексний аналіз статей 5, 245 КАСУ дає можливість припустити, що визначені у них способи захисту не $є$ виключними. Суду дозволяється обирати інший спосіб - той, який він вважає найдієвішим.

Крім цього, ми не можемо не враховувати принцип офіційного з'ясування всіх обставин у справі, який виокремлює адміністративне судочинство від інших судових процесів, згідно з яким суд може вийти за межі позовних вимог, якщо це необхідно для ефективного захисту прав, свобод, інтересів людини і громадянина, інших суб’єктів у сфері публічно-правових відносин.

Отже, адміністративному суду надається компетенція самостійно визначати спосіб захисту особи, який не встановлений норами КАСУ, але який не суперечить закону i забезпечує ефективний захист права. Таким чином, тепер суд визначає ефективність способу захисту. Якщо спосіб захисту, про який просить позивач і який встановлений нормами КАСУ, на думку суду, не дає дієвого результату, під час розгляду адміністративної справи суд самостійно визначає інший спосіб, який забезпечує максимальну ефективність захисту. При цьому застосований судом спосіб захисту не має суперечити закону.

Відповідні положення, які закріплені у новій редакції КАСУ з 2017 року, перекликаються із засадами, що проголошуються у Конвенції про захист прав людини i основоположних свобод. Так, стаття 13 Конвенції передбачає право на ефективний засіб правового захисту, зазначаючи, що «кожна людина, чиї права та свободи, визнані в цій Конвенції, були порушені, має право на ефективний засіб юридичного захисту в національному органі, навіть якщо таке порушення було вчинене особами, які виступають як офіційні особи» [18].

3 огляду на те, що чинні норми КАСУ надають адміністративному суду самому визначати спосібзахисту, враховуючи нашаналіз, вважаємо, щонорми процесуального 
права також дають змогу суду самостійно визначати ступінь втручання суду в розсуд публічної адміністрації. Втручання адміністративного суду в адміністративний розсуд зумовлюється процесуальними повноваженнями, які надаються йому КАСУ під час вирішення спору.

Положення зазначених вище статей КАСУ дають підстави вважати, що втручання адміністративного суду за підсумками розгляду та вирішення адміністративної справи може проявлятися, зокрема, у покладанні на суб'єкта владних повноважень: обов’язку прийняти адміністративний акт чи інше рішення; обов'язку вчинити дії у межах наданого адміністративного розсуду; обов'язку утриматися від дій, які виходять за межі адміністративного розсуду; обов'язку розглянути звернення чи питання особи; обов'язку повторно розглянути питання особи; обов'язку повторно прийняти процедурне рішення (вчинити дію); обов'язку утриматись від подальшого виконання процедури, яка б виконувалась на підставі рішення, яке визнане протиправним; обов'язку прийняти дискреційне рішення; обов'язку вчинити певну дискреційну дію; заборони подальшої реалізації протиправного дискреційного рішення чи продовження вчинення дії та ін. Слід наголосити, що перелічені нами способи втручання адміністративного суду не є вичерпними, оскільки норми процесуального права дають суду можливість самому визначати межі такого втручання.

У науковому середовищі тривалий час точаться дискусії з приводу того, чи має суд повноваження зобов'язувати суб'єкта владних повноважень прийняти конкретне рішення чи вчиняти певну конкретну дію, які той має відповідно приймати та здійснювати «на власний розсуд». Вважаємо, що в окремих випадках суд може для своєчасного захисту права особи зобов’язати відповідача прийняти рішення конкретного змісту чи вчинити конкретну дію. Спосіб відновлення порушеного права у разі встановлення факту протиправності рішення чи дії суб'єкта, наділеного владою, під час процесу виборів або референдуму, на нашу думку, має бути таким, який виключає подальші протиправні рішення чи дії, щоб з огляду на швидкоплинність цих процесів, у разі невиконання або неналежного виконання судового рішення колегіальним органом виборчою комісією чи комісію з референдуму не виникала б необхідність повторного звернення із позовом до суду, але здійснювалося примусове його виконання.

Прояв втручання у розсуд колегіального суб'єкта публічної адміністрації, на нашу думку, так само може бути таким, який випливає із повноважень суду, визначених y КАСУ, але і таким, який вибере суд самостійно, враховуючи окремі чинники та встановлені ним обставини, що мають значення для правильного вирішення справи. Втручання суду у адміністративний розсуд колегіального суб'єкта, який є відповідачем у адміністративній справі, не має суперечити закону і безпідставно вмішуватись у функцію цього владного суб'єкта, має забезпечувати ефективний захист прав, свобод та інтересів позивача.

Висновки. Резюмуючи, зазначимо, що питання стосовно способів судового захисту від протиправної поведінки колегіальних суб'єктів публічної адміністрації потребує подальшого дослідження. Звертаємо увагу на те, що чинні норми процесуального права надають адміністративному суду самому визначати спосіб захисту особи. Суд самостійно визначає, який спосіб захисту є максимально ефективним і повністю відновлює становище, яке існувало до порушення права, і застосовує його. Втручання 
адміністративного суду у розсуд колегіальних суб’єктів публічної адміністрації, з огляду на види публічно-правових спорів за їх участю, у сучасних умовах є неминучим. Межу втручання суду в управлінський розсуд колегіального суб'єкта публічної адміністрації також визначає суд самостійно. Законодавство дає змогу суду самому обирати ступінь втручання в адміністративний розсуд. Доходимо висновку, що головними умовами такого втручання має бути те, щоб воно не суперечило закону, не перевищувало повноважень суду та усувало перешкоди у реалізації права позивачем. Обмеження судового контролю та втручання адміністративного суду у адміністративний розсуд суб'єктів владних повноважень, у тому числі і колегіальних, звужуватиме право особи на належний правовий захист від порушень з їхнього боку.

\section{Лimepamypa}

1. Рісний М.Б. Правозастосувальний розсуд (загальнотеоретичні аспекти) : автореф. дис. ... канд. юрид. наук : 12.00.01. Львівський національний ун-т імені Івана Франка. Львів, 2006. 16 с.

2. Савчин М. Свобода суддівського розсуду у світлі обгрунтованості рішень судів апеляційної та касаційної інстанцій. Юридичний вісник України, 2016, 22 липня, № 28. URL: http://yurincom. deploy.am.com.ua/svoboda-suddivskogo-rozsudu-u-svitli-obgruntovanosti-rishen-sudiv-apelyatsijnoyita-kasatsijnoyi-instantsij/.

3. Личман Л. Судейское усмотрение (теоретический и гражданско-процесуальный аспекты). Legea si Viata. 2014. № 2/3 (266). P. 60-63.

4. Бевзенко В.М., Панова Г.В. Сутність та підстави втручання адміністративного суду у розсуд публічної адміністрації : монографія / за заг. ред. В.М. Бевзенка. Київ : ВД «Дакор», 2018. 232 с.

5. Ільницький 0. Обрання способу судового захисту у справах із використанням дискреційних повноважень суб’єктами публічної адміністрації. Підприємництво, господарство і право. 2017. № 4. С. 108-113.

6. Лист Верховного Суду України від 29 жовт. 2008 № 19-3767/0/8-08. URL: http://www.ligazakon.ua.

7. Постанова Пленуму Вищого адміністративного суду України «Про судове рішення в адміністративній справі» від 20 трав. 2013 року № 7. URL: http://zakon0.rada.gov.ua/laws/show/v0007760-13.

8. Пуделька Й. Понятие усмотрения в административном праве Германии и его отграничение от судебного устройства. Вестник СПбГУ. Право, 2017. Т.8. Вып. 4, с. 443-451. URL: https://doi.org/10.21638/11701/spbu14.2017.406.

9. Савенко М.Д. Суддівський розсуд у цивільному процесі. Наукові записки. Юридичні науки : зб. наук. праць. Т. 26. Київ, 2004. С. 75-79.

10. Сеньків О.І. Адміністративно-правові підходи щодо визначення сутності поняття і функцій судового розсуду. Вісник Південного регіонального иентру Національної академї правових наук України. 2016. № 6. C. 46-54. URL: http://nbuv.gov.ua/UJRN/vprc_2016_6_8.

11. Мельник Г.П. Судовий розсуд (дискреція) як явище правової системи. Наукові записки НаУКМА. Київ, 2009. Т. 90. Юридичні науки. С. 44-47.

12. Барак Аарон. Судейское усмотрение: монография / Перевод с английского. Москва : Норма, 1999. $376 \mathrm{c}$.

13. УхвалаВищого адміністративного суду України від 12 січ. 2017 року, справа№К/800/21531/16. Єдиний державний реєстр судових рішень. URL: http://www.reyestr.court.gov.ua/Review/64262061.

14. Рішення Європейського суду з прав людини у справі «Олссон проти Швеції» від 24 берез. 1988 року (скарга № 10465/83). URL: http://europeancourt.ru/uploads/ECHR_Olsson_v_ Sweden_N_1_28_03_1988.pdf.

15. Панова Г.В. Деякі особливості втручання адміністративного суду у розсуд суб'єкта публічної адміністрації. Науковий вісник Херсонського державного університету. Серія «Юридичні науки». 2017. Випуск № 3. Том 2. С. 43-47.

16. Цвіркун Ю.І. Колегіальність суб'єктів публічної адміністрації. Науковий вісник Міжнародного гуманітарного університету. Серія «Юриспруденція». 2016. № 23. С. 70-73.

17. Про внесення змін до Господарського процесуального кодексу України, Цивільного процесуального кодексу України, Кодексу адміністративного судочинства України та інших законодавчих 
актів : Закон України від 3 жовт. 2017 р. № 2147-VIII / Верховна Рада України. URL: http://zakon2.rada.gov.ua/laws/show/2147-19.

18. Конвенція про захист прав людини і основоположних свобод від 04.11.1950. URL: http://www.ligazakon.ua.

\section{Анотація}

Цвіркун Ю. І. Щодо втручання адміністративного суду у розсуд колегіальних суб’єктів публічної адміністрації. - Стаття.

Стаття присвячена такому явищу, як втручання адміністративного суду у розсуд суб'єкта публічної адміністрації - колегіального органу. У ній здійснено правовий аналіз підходів до розуміння цього явища, яке, на нашу думку, повною мірою стало можливим із впровадженням в Україні адміністративного судочинства і має тенденції до поширення. Досліджено, що втручання адміністративного суду у розсуд органу виконавчої влади, органу місцевого самоврядування чи іншого суб'єкта владних повноважень може відбуватися, як правило, у разі здійснення так званого «правозахисного» процесуального розсуду. Зроблено висновок, що адміністративний суд має повноваження втручатися у розсуд публічної адміністрації на підставі закону. Таке втручання здійснюється судом з метою відновлення порушених прав, свобод та інтересів особи. Зауважено, що чітких меж втручання суду у розсуд суб'єкта публічної адміністрації закон не установлює і ці межі визначаються судом самостійно з урахуванням певних чинників.

Ключові слова: колегіальний суб’єкт публічної адміністрації, адміністративний розсуд, управлінський розсуд, суддівський розсуд, втручання, адміністративне судочинство.

\section{Аннотация}

Цвиркун Ю. И. О вмешательстве административного суда в усмотрение коллегиальных субъектов публичной администрации. - Статья.

Статья посвящена такому явлению, как вмешательство административного суда в усмотрение субъекта публичной администрации - коллегиального органа. В ней дан правовой анализ подходов к пониманию этого явления, которое, по нашему мнению, в полной мере стало возможным с внедрением в Украине административного судопроизводства и имеет тенденцию к распространению. Доказано, что вмешательство административного суда в усмотрение органа исполнительной власти, органа местного самоуправления или иного субъекта властных полномочий может происходить при осуществлении так называемого «правозащитного» процессуального усмотрения. Сделан вывод, что административный суд уполномочен вмешиваться в усмотрение публичной администрации на основании закона. Такое вмешательство осуществляется судом с целью восстановления нарушенных прав, свобод и интересов человека. Замечено, что четких границ вмешательства суда в усмотрение субъекта публичной администрации закон не устанавливает и эти границы определяются судом самостоятельно с учётом определённых факторов.

Ключевые слова: коллегиальный субъект публичной администрации, административное усмотрение, управленческое усмотрение, судейское усмотрение, вмешательство, административное судопроизводство.

\section{Summary}

Tsvirkun Yu. I. On the intervention of the administrative court at the discretion of the collective subjects of public administration. - Article.

The article is devoted to such a phenomenon as the intervention of the administrative court at the discretion of the subject of public administration - a collegial body. It provides a legal analysis of approaches to understanding this phenomenon, which, in our opinion, became fully possible with the introduction of administrative proceedings in Ukraine and has a tendency to spread. It is proved that the intervention of the administrative court at the discretion of the executive authority, local government or other subject of authority may occur in the exercise of the so-called "human rights" procedural discretion. It is concluded that the administrative court is authorized to intervene in the discretion of the public administration on the basis of the law. Such intervention is carried out by the court in order to restore the violated rights, freedoms and interests of the person. It was noted that the law does not establish clear limits for court intervention at the discretion of the subject of public administration and these limits are determined by the court independently, taking into account certain factors.

Key words: collegial subject of public administration, administrative discretion, managerial discretion, judicial discretion, interference, administrative proceedings. 